\title{
MONGOLIA'S ASIA-PACIFIC POLICY AND REGIONAL SECURITY STRATEGY
}

Keynote address by H.E. Nyamosor Tuva. Acting Prime-Minister and Minister for External Relations of Mongolia at the Asia-Pacific Group Meeting of the International Parliamentary Union

Excellencies,

Ladies and Gentlemen:

Let me start by saying that it is a great honor for me to have this opportunity to address such a distinguished audience of regional Parliamentarians on issues related to Mongolia's Asia-Pacific policy and her regional security strategy. I know that you have stayed here since quite a while and I am sure that, in the past couple of days, you have had the chance to loam more about what we are doing here in Mongolia to advance our development goals and build cooperative relations with the world around us.

I must say that the Asia-Pacific region and relations with regional countries have been high on my agenda in the past several months. I am just back from the Ministerial Meeting of the ASEAN Regional Forum in Singapore, where Ministers discussed regional security issues. This year we had a number of important high-level visits to Mongolia by regional leaders: visit by President Kim Dae-jung of the ROK, visit by Prime-Minister Keizo Obuchi of Japan and then visit by President Jiang Zemin of the PRC. And I have recently traveled to Russia for talks with Russia's Foreign Minister. My first trip abroad as Minister for External Relations was also to Asia, to Bangkok, where I chaired the annual session of the ESCAP. And earlier in May I visited Japan. So, from my perspective as Minister for External Relations, I should say that it is a very timely conference that you are holding here in Mongolia.The way in which we in Mongolia view the world around us has been profoundly affected by the tremendous changes that have taken place in our society and international and regional environment since the end of the Cold War. Domestically, we have moved away from a closed society with totalitarian rule and planned economy to an open society with democratic government and a market-oriented economy. This has not been an easy transition but, by and large, we have been successful. We have built solid institutions of representative democracy which have withstood the test of several elections. Government change proceeds smoothly without endangering the democratic process. Successive governments have worked, since the early 1990s, to build a more liberal, market-oriented environ- 
ment conducive to a private sector-led development. The challenge before the government now is to proceed further and firmly with the economic reform in the face of budgetary and social constraints and unfavorable developments in the external sector.

Internationally, we face a world where interplay of forces of continuity and change, of globalization and localization makes this world a more complex place, and calls for an increased international cooperation to respond to the challenges of the new era. For the purposes of this presentation let me first offer our broader perspective on the current international situation, then narrow the perspective to look at the Asia-Pacific region and finally speak of our response to what we see.

\section{Current international situation.}

I believe that, by now, the following trends can, tentatively, be said to have become more or less evident. Trade and economic activity are becoming increasingly important in international politics; economic interdependence and globalization have emerged as a major global trend. As a result, managing these processes in such a way as to ensure equitable development and avoid marginalization of the weak and vulnerable, has become a major challenge. The Asian financial crisis that spilled over to other parts of the world has made it acutely evident that a major adaptation is needed - in individual countries, regionally and globally - to address the opportunities and the challenges associated with the globalization. We feel that a more comprehensive approach to reform needs to be adopted domestically which should include the regulatory framework, including macroeconomic policies, but also governance issues, social and human aspects of development as well as environmental sustainability. It is our concern that, left unattended, uneven economic development, social inequalities and a wider gap between the poor and the rich may be fraught with instabilities in individual countries that can spill over to threaten wider regional and international stability. The crisis has been, I believe, a reminder to us of the linkages that exist between economic and political security. Another trend that is visible is that, along with the conventional security threats such as weapons proliferation, "unconventional" threats to security such as international terrorism, drug-trafficking, organized crime, energy, population and so on pose a strategic challenge throughout the world. This has been attested by the agenda of various international and regional forays in recent years. We feel it important that governments cooperate among each other and with the non-governmental organizations to address these transnational challenges. 
Information revolution is affecting all areas of human activity and is likely to have a growing impact on the ways in which we think and work in the next century. The world is becoming a smaller and more open place with cheaper travel and cheaper communications! One effect this has had on global affairs is the emergence of an informed Tran boundary of academics, parliamentarians, interest groups and businesses willing to influence the terms of international debate at various levels. Information revolution has also been accompanied by a movement towards greater democratization which has marked the last decades of this century. But there have also been negative developments such as terrorists and criminals acquiring new technology and crossing borders and threatening stability and killing innocent people. International terrorism must be fought by joint efforts and resolutely condemned.

Along with the emerging new challenges the world is still faced with such long-standing security threat as weapons proliferation. In past years a major progress has been made in non-proliferation and anus control sphere: the NPT has been indefinitely extended, the CTBT has been opened for signature, the $\mathrm{CWC}$ entered into force, and the LBC entered into force, work is in progress with regard to the strengthening of the BWC. In the face of the challenge of proliferation we think it is important to strengthen the non-proliferation regime with an objective of moving closer to nuclear disarmament, and redouble the efforts aimed at the prevention of the spread of the weapons of mass destruction.

Though with the end of the Cold War the danger of a global war has disappeared rise of nationalism, ethnic tensions and conflicting territorial claims have led to armed conflicts in various parts of the world. They constitute a source of instability throughout the world and can endanger international peace and security. We believe it important that nations work together to build preventive capacities that can help identify and address the causes of disputes before they escalate into conflicts.

In past years major powers have undertaken to stabilize relations between each other through exchanges of visits and dialogues on issues of common interest. We believe that stable relations between major powers and their cooperation are of enormous importance in ensuring and enhancing regional and international peace and stability.

\section{Asia-Pacific region}

At the end of the bipolar confrontation, we have seen a substantial improvement in the regional security environment. This was also due to the common preoccupation with the economic growth that has been the region's overrid- 
ing concern in past years. The major challenge now before the region is to preserve the environment of peace and stability in the face of current uncertainties.

We believe it to be an important achievement for the region that the nations in the region have been able to build the ARF multilateral consultative body to discuss security concerns. The confidence-building measures implemented by the ARF members play, in our view, an important role in enhancing mutual understanding and fostering the habits of dialogue and cooperation in the Asia-Pacific region.

With regard to North-East Asia, the situation on the Korean peninsula remains a concern. We believe it important that such dialogue avenues as interKorean dialogue and the four-party talks be further pursued to reduce tension and improve the overall security on the peninsula. We also believe that continued implementation of the non-proliferation and arms control regimes is essential in preserving regional peace and stability. Cooperation of major powers on issues of common interest is also important in maintaining peace and security in North-East Asia.

We highly value ASEAN's role in maintaining regional stability and fostering regional cooperation. Its longstanding record of cooperation, good-neighborliness and dialogue has contributed in a major way to the cause of peace and stability in the region. APEC, through its liberalization efforts and Economic Leaders' meetings, also contributes its own share to mutual understanding and regional cooperation. With regard to regional affairs, the valuable role played by "track two" dialogues in promoting regional cooperation both in economic and political spheres is also to be noted.

\section{Mongolia's response.}

Now let me discuss Mongolia's response. In the early 1990s, when the Cold War ended, the bipolar confrontation was gone, and an effective regime change occurred in Mongolia - and Mongolia opened herself up to the outside world - we found ourselves confronted with the double challenge of responding to the immediate need to redefine Mongolia's foreign and security policy priorities, and adjusting, on a longer term, to the challenges of globalization and economic liberalization. As a response, we conducted a major review of our foreign and security policy which resulted in the endorsement by the Parliament of two basic documents called Concept of Foreign Policy and Concept of National Security. We adopted what was termed as a multi-pillar foreign policy and a comprehensive approach to national security. Mongolia's multi-pillar foreign policy signified its desire to maintain balanced and good-neighborly 
relations with Russia and China, our sole neighbors, develop closer relations with other countries in the world and in the region, including such key nations as the US and Japan, and engage more broadly in various areas of regional and international cooperation to advance our small-and-developing country perspective. In the face of an increasingly interdependent world, a novel international economic and security environment and evolving global and regional realities we think it important to maximize the benefits offered by international and regional multilateral cooperation to pursue the nation's development and security goals. Hence our more active work in the UN, fresh membership in such organizations and foray as international financial institutions, the WTO, the ARF. We also expressed our desire to join the APEC.

According to our comprehensive approach, Mongolia's national security encompasses a number of components such as security of the existence of the Mongolian nation which is defined as Mongolia's vital national interest, economic security described as the cornerstone of Mongolia's independence and sovereignty, environmental security, information security etc.

In the 1990s the Asia-Pacific region emerged as a new and important direction for our foreign policy. In that region our policy goals consist in the following. Enhancing mutual understanding through exchanges of visits, promotion of political dialogue and cultural exchanges. In the 1990s we worked to diversify our external ties in political, economic, trade and military spheres with regional countries. There have been exchanges of visits at various levels, which helped engage us more actively with the Asia-pacific region. Developing trade and economic ties with the region through creating opportunities for increased bilateral trade; encouraging links between private sectors; encouraging foreign direct investment; where appropriate, seeking aid in major areas of reform; engaging with the APEC process; seeking membership in PECC; supporting multilateral economic cooperation in North-East Asia. In North-East Asia, we participate in the Tumen river project. We also work to promote sub-regional cooperation of land-locked and transit countries. We take part in some of the APEC working groups as a guest participant and have developed our own Individual Action Plan of trade and investment liberalization in accordance with the APEC model. Enhancing Mongolia's security environment through building a multipillar framework for security. Let me elaborate on that.

\section{Mongolia's regional security strategy}

In the Asia-Pacific region our security strategy consists in building a multi-pillar framework of security by a) maintaining friendly good-neighbourly 
relations with our neighbours; b) developing closer bilateral relations with other regional countries; c) working within the ARF multilateral process; d) contributing to North-East Asian peace and stability; e) developing military-to-military contacts; f) implementing global non-proliferation and arms control regimes, g) and encouraging "track two" dialogues on security issues.

The end of the Cold War substantially improved Mongolia's immediate security environment by bringing about improvement of relations between Russia and China which we see as a major stabilizing factor. Our relations with Russia and China, our sole neighbours, are governed by such principles as balance, good-neighbourliness, mutually beneficial cooperation, long-term nature. Mongolia signed respective Treaties of Friendly Relations and Cooperation with Russia and China. We do not have any territorial or border disputes with our neighbours which serves as a good basis for our good-neighbourly relations.

As part of our effort to contribute to nuclear non-proliferation and disarmament, in 1992 Mongolia declared its territory a nuclear-weapon-free-zone. In December last year the UN General Assembly adopted a resolution entitled Mongolia's International Security and Nuclear-Weapon Free Status. At the ARF Meeting on Monday the Ministers welcomed this resolution.

Since the early 1990s Mongolian scholars have been taking part in what is called "track two" activities on regional security. Since 1996 Mongolian scholars work with the CSCAP and are active in its North-Pacific working group. There have been regular exchanges, and several bilateral roundtables on regional security issues were held. This concludes my remarks on Mongolia's Asia-Pacific policy and our regional security strategy. As we approach the $21^{\text {st }}$ century, I think it very important that representatives from the

Asia-Pacific region interact more closely between each other and among themselves to be able to develop common responses to the challenges of the coming age. And I see the value of your conference in that it helps promote mutual understanding, dialogue and cooperation as we approach a new century.

Thank you very much. 